\title{
Land Use and Land Cover Change in Northeast Gadarif State: Case of El Rawashda Forest, Sudan
}

\author{
Yousif Elnour Yagoub1,2*, Zhang Bo', Ji Ding-min'1, Abdelraheim Elobeid Jahelnabi1,3, \\ Sona Mohammed Fadoul1,2 \\ ${ }^{1}$ College of Geography and Environmental Science, Northwest Normal University, Lanzhou, China \\ ${ }^{2}$ Department of Forest Conservation and Protection of Forest, Faculty of Forestry, University of Khartoum, \\ Shambat, Sudan \\ ${ }^{3}$ Department of Agricultural Engineering, Faculty of Agriculture, University of Khartoum, Shambat, Sudan \\ Email: 'yousifelnouryagoub@yahoo.com
}

Received 29 February 2015; accepted 9 April 2015; published 15 April 2015

Copyright (C) 2015 by authors and Scientific Research Publishing Inc.

This work is licensed under the Creative Commons Attribution International License (CC BY).

http://creativecommons.org/licenses/by/4.0/

(c) (i) 0 pen Access

\section{Abstract}

The main objectives of this study were to detecting the land use and land cover change (LULC), using remote sensing techniques, then identify the reasons for rangeland and tree cover degradation in El Rawashda Forest, Gadarif State, Sudan. The study has conducted field experiment developed on an area of 20 feddans that was affected by deterioration in the forest and to assess the best method for rehabilitation of the vegetation cover in the area of study. The experimental area was divided into 5 blocks; each block consisted of 4 treatments: grass seeds and Talih (Acacia seyal var. seyal); sowing seeds just before autumn, sowing seeds after disc ploughing, sowing seeds using water harvesting technique and control (no seeding). In the present study an attempt has been made to analyze and monitor the LULC changes using multi-temporal Landsat data deterioration in the forest and to assess the best method for restoration of the vegetation. In the present study, an attempt has been made to analyze and monitor the LULC changes using multi-temporal Landsat data for years 1984, 1994 and 2013. LULC grades in the classification scheme are: Trees, Mechanized Rain-fed Agriculture (MRA), Grasses and Bare land. Individual classifications based on maximum likelihood of algorithm were used and the results showed a significant that extensive change of LULC patterns has occurred in all decades in the study area. The results also show Trees class was decreased, while MRA, Grasses and Bare land were increased. The seeding of the forage and Talih seeds after disc plowing gave the best results compared to the other treatments, followed by forage and Talih seed sowing under the water harvesting technique and broadcasting of forage and Talih seeds and finally the control.

\footnotetext{
${ }^{*}$ Corresponding author.
} 


\section{Keywords}

\section{Land Use and Land Cover, Remote Sensing, Mechanized Rain-Fed Agriculture, El Rawashda Forest}

\section{Introduction}

Sudan is rich in its natural resources; the forest resources are among them, which are either reserved, or nonreserved. They play vital role in the economy and welfare of the people. Forest provides a wide range of benefits including fire wood for energy, pole and sawn timber beside non-wood forest products like Gum Arabic. [1] stated that, forest cover in Sudan is estimated to be $12 \%$ of the total area of the country while it was $18 \%$ during early 1980 and 36\% during 1950. Large scale mechanized rain-fed agriculture was developed in the Gadarif Region in 1945, when the Colonial British Government decided to cultivate the cracking clays of Central Sudan in order to meet the food needs of army units in East Africa. During the 1960s, investment from the private sectors resulted in a massive clearing of land for cultivation. As a consequence, fallow lands occurred every 4 years while the investors continuously cleared the new areas. By the end of 1970s and in the early 1980s, most of the lands were used for mechanized farming [2]. This situation, coupled with several other factors such as monocropping of sorghum, lack of crop rotation, inappropriate methods of soil preparation and management, had resulted in severe land degradation problems. Rapid physical, chemical and biological deterioration of soil and subsequent decline of agricultural productivity and deterioration of environment have taken place within this region [3]. In the dry seasons at El Rawashda forest, the nomads have no alternative for animal feeding except lopping the trees. In addition to the continuous lopping of the trees as fodder, their livestock causes damage to the forest particularly the regeneration. Rangeland miss-use and open grazing by villagers and nomads during their seasonal movement from North to South Gadarif state and their stay for a longer period in the forest exposes its resources to further depletion. The total forest area is reduced due to over cultivation by modern mechanized farming as a result of increase in food demand due to human population increase as well. Deforestation for charcoal, building houses and fire wood to improve their economic income has contributed to forest deterioration. Thus, The Sudanese villages and camps of Eritrean refugees near the El Rawashda forest has a negative impact on the forest that led to change in LULC by over-logging and open grazing. LULC changes are among the most persistent and important sources of recent alterations of the Earth's land surface. Remote sensing with high temporal resolution images has become a very strong tool for monitoring LULC changes [4]. Remote sensing for many purposes provides the only way to assess habitat structure and LULC changes across the vast areas [5]. For the mapping of LULC changes, the use of satellite images is becoming increasingly important) [6]-[9]. The objectives of the present study were 1) to study the land use and land cover (LULC) detection using multi-temporal Landsat data in El Rawashda forest, Gadarif State; and 2) to identify the reasons of rangeland and tree cover degradation in the study area. In order to achieve the above objectives the following hypotheses have been put forward to be empirically tested: The forest and rangeland resources have been depleted as a result of miss-management. The uncontrolled open grazing system leads to the deterioration of range recourses. The man made activities are contributing potentially in degradation of El Rawashda Forest Reserve.

\section{Study Area}

The study area is located in EI Rawashda natural forest reserve is the largest forest in Gadarif state. It lies between Gadarif and Showak at latitude $14^{\circ} 6^{\prime}-14^{\circ} 24^{\prime} \mathrm{N}$ and longitude $35^{\circ} 32^{\prime}-35^{\circ} 49^{\prime} \mathrm{E}$, covering an area of about 121472.6 feddans (Figure 1). Gadarif State vegetation cover is composed of great diversity of trees, shrubs and grasses. The average temperature of this region varies between a mean minimum of $22^{\circ} \mathrm{C}$ in winter and a mean maximum of $37^{\circ} \mathrm{C}$ in summer. The study area receives the highest temperature between April and May. During such times, the hottest day can go up to $40^{\circ} \mathrm{C}-42^{\circ} \mathrm{C}$ [10]. The forest has been gazzetted in 1960 as a central forest reserve under 1932 central forest ordinance to safeguard the charcoal supplies for Khartoum [11]. Generally, the vegetation of the area is largely dependent on rainfall and soil types. Despite the high deforestation trends in El Rawashda natural reserve forest still vegetation cover is composed of great diversity of trees, shrubs and grasses. The main dominant trees are: Acacia seyal var. seyal (Tailh) is covering $70 \%$ of the total area of the forest, Acacia senegal (hashab) mainly planted but some naturally growing trees are mixed in (Talih) stand, 


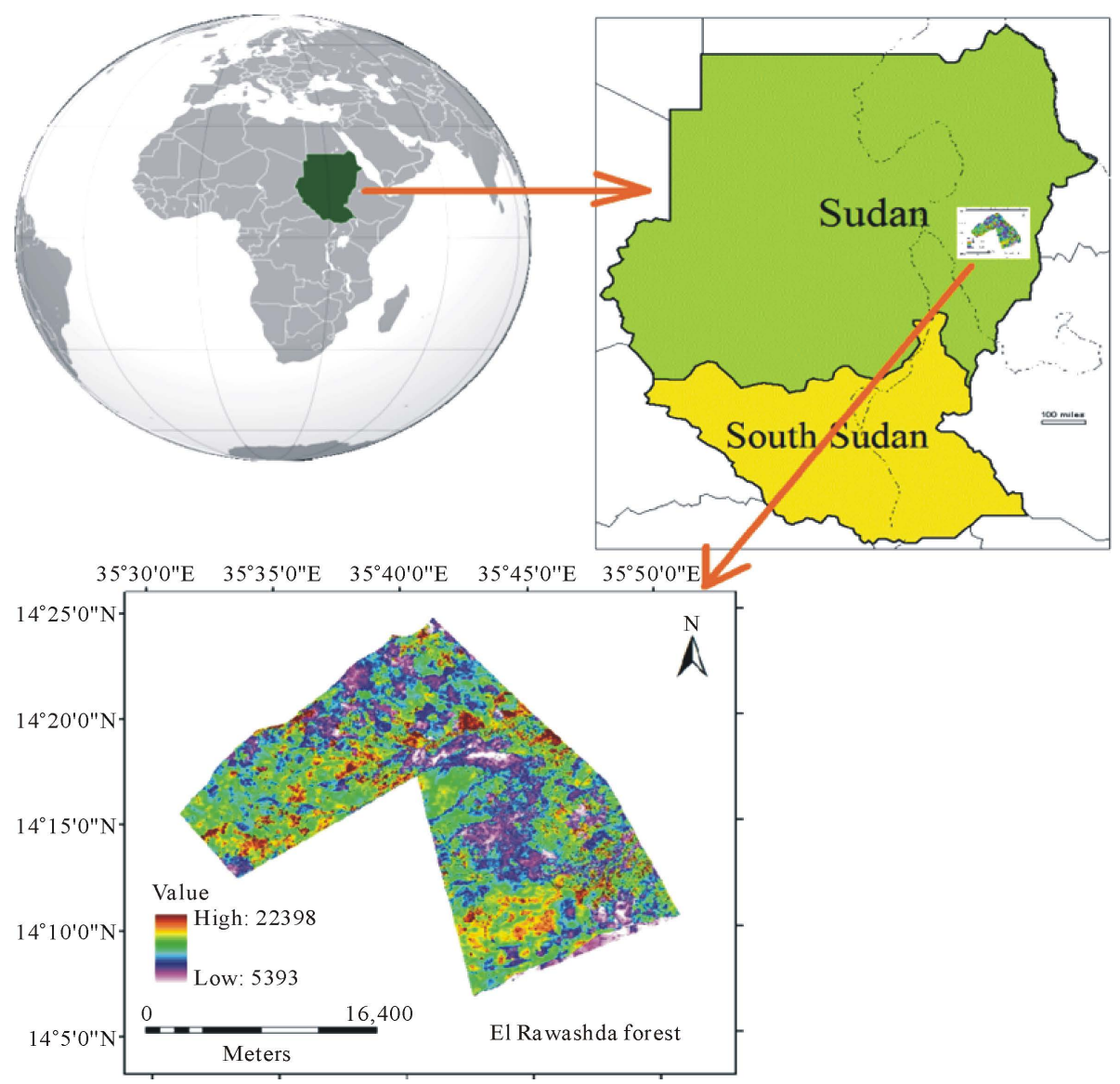

Figure 1. Study area.

Acacia millifera (Kitr) large shrub, Acacia nubica (Laot) is a small shrub in some pockets in the northern part of the forest and Balanites aegyptiaca (Higlig) is dominant trees scattered throughout the forest. The obvious feature of El Rawashda forest is the dominance of grasses and herbs including: Cortolaria senegalensis (Safari), Ocimum basilicum (Rehan), Ipomea cardiosepala (Hantoot), Ipomea cordofanam (Taber), Solanuim dubium (Jubein), Sorghum halpens (Adar), Aristida mutabilis (Gaw), Cympopogn nervatus (Nal), Pennisetum spp. (Danab kadees) Tribulus terrestris (Derisa) and Phragmites spp. (Boos).

Monthly rainfall and temperature data were obtained for the meteorological station of El Gadarif (latitude $14.03^{\circ} \mathrm{N}$; longitude $35.40^{\circ} \mathrm{E}$; altitude $600 \mathrm{~m}$ ) from Sudan Meteorological Authority. Standardized anomaly indices (SAIs) were calculated for the annual mean temperatures as well as the rainfall data to assess the evolution of climatic departures from the normal. Figure 2(a) and Figure 2(b) showed annual temperature, Figure 3(a) and Figure 3(b) showed annual rainfall and Figure 4 showed monthly rainfall. The region is characterized by semiarid climatic conditions with an aridity index ranging from 0.2 to 0.4 [12].

\section{Materials and Methods}

The first visit was carried out to El Rawashda forest to up-date information on the area and establish a boundaries for the area (i.e. remapping) using Global Positioning System (GPS). Primary data of the past forest status (e.g. area and type of trees species), was collected by reviewing the reports available from the Forest National Corporation (FNC) and Range and Pasture Administration in Gadarif State, and other relevant literature. The sources of secondary data include FNC documents, files, annual reports and relevant articles.

\subsection{The Experiment Layout and Field Work}

The most deteriorated areas were identified in different places and were considered as the experimental site of 


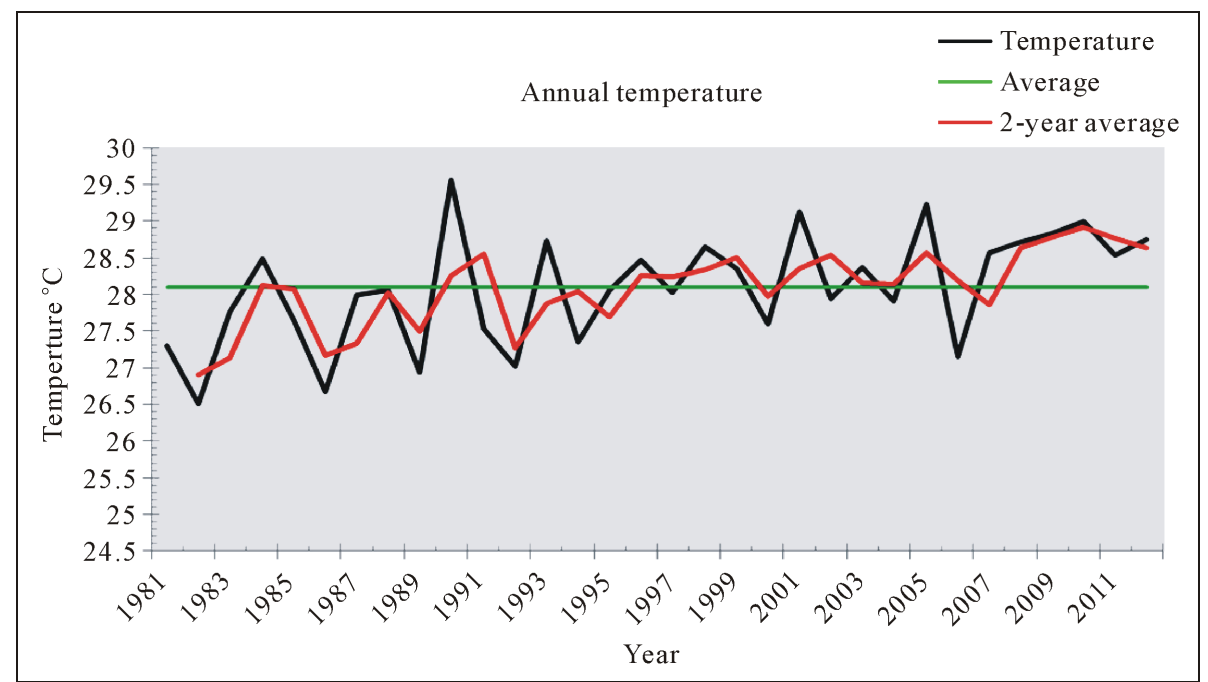

(a)

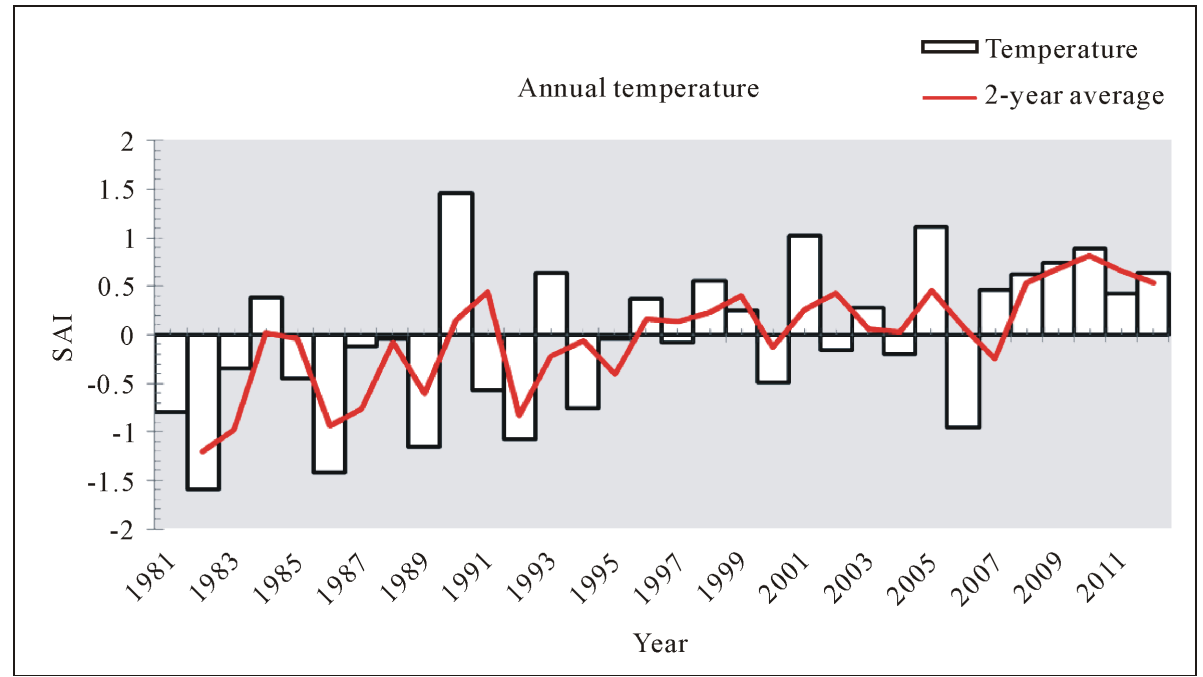

(b)

Figure 2. Annual temperature in El Rawashda forest in 1981-2012.

about 20 feddans (Feddan = 0.42 ha.). These were further divided into five parts with four feddans for each one as separate unit. In each unit (four Feddans), four treatments were applied as means of vegetation cover improvements. The experimental design was completely randomized block design (CRBD). Treatment means were separated using the LSD test [13]. The designated treatments which were conducted are; Broadcasting forage and trees seeds just before autumn, broadcasting forage and trees seeds after disc ploughing in autumn, forage and trees seed sowing with water harvesting in autumn and control. The experiment was conducted in rainy seasons of 2008 and 2009. In each of the two years the following measurements for forage plant were taken according to [14]. Productivity and plant density per unit area were measured by quadrate, and vegetation cover was measured by visual estimates and transects method.

\subsection{Satellite Images}

Thematic Mapper (TM) and OLI/TIRS (OLI = Operational Land Imager and TIRS and Thermal Infrared Sensor) multi-spectral images are the main remote sensing data used in current study. Multi-temporal Landsat data of the years 1984, 1994 and 2013 with a path/row of 171/50 were used in this study. The technical details of Landsat 4 - 5 TM and Landsat 8 OLI/TIRS bands have been provided in the Table 1. For other specification of Landsat 


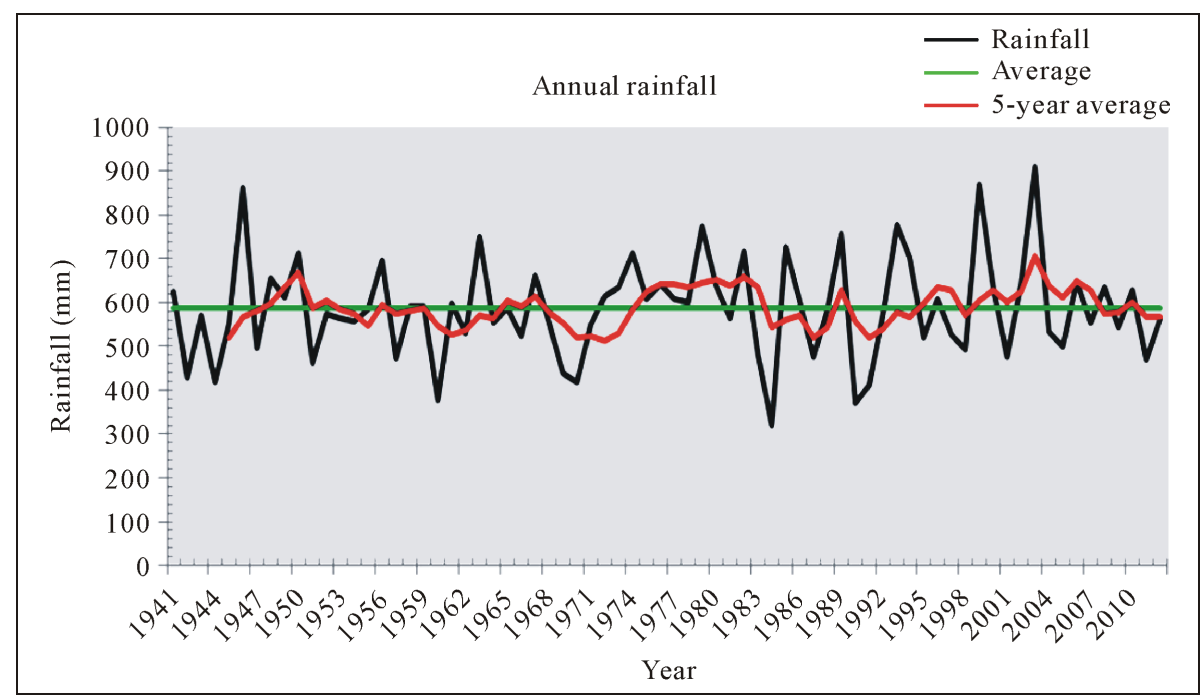

(a)

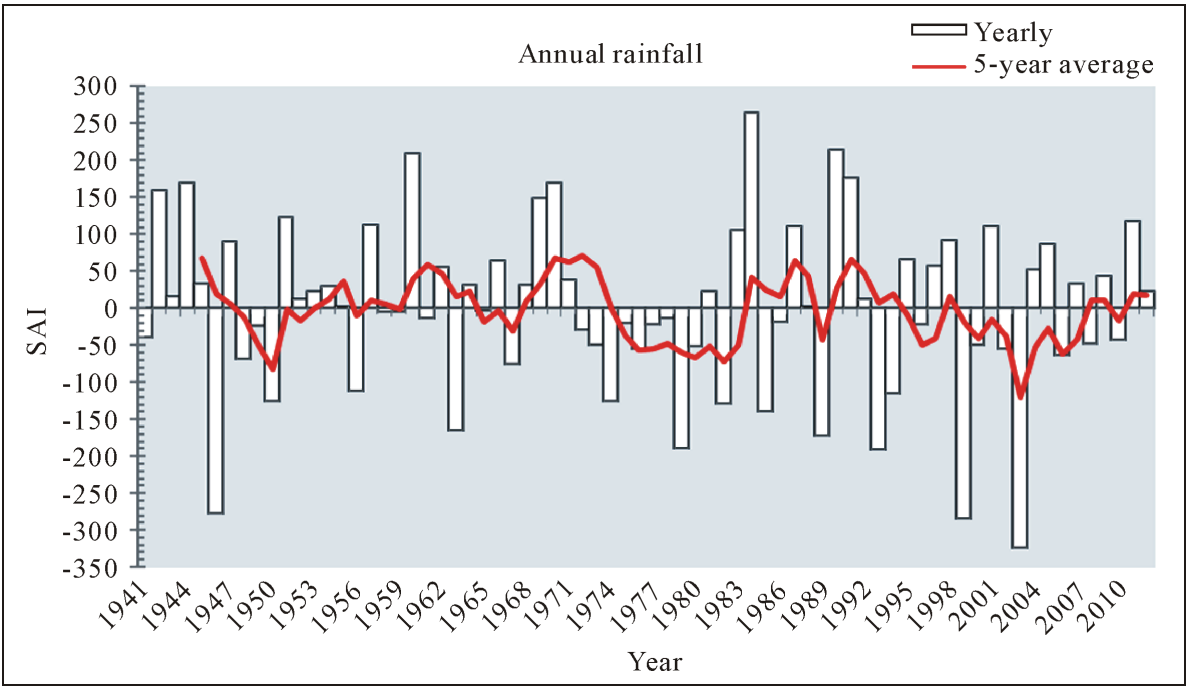

(b)

Figure 3. (a) and (b) annual rainfall in El Rawashda forest in 1941-2012.

satellite; refer to the official portal of Landsat (Landsat Program, NASA web). The Landsat TM and OLI/TIRS scenes of path and row that are given in Table 1 were used for El Rawashda forest that downloaded from USGS web (http://earthexplorer.usgs.gov/). Post-classification is a term describing the comparative analysis of spectral classifications for different dates produced independently [15]. Despite criticisms focusing on accumulation of the inherent errors of each individual classification, this is the most appropriate method for comparing multisource data, as each data layer can be generalized to a common LULC scheme before being compared [16]. In order to quantify changes of certain LULC type during certain time period, the calculation formula followed was:

$$
\text { LULCC }=\frac{\text { LULC }_{b}-L_{L L C}}{L_{a}} \times \frac{1}{\mathrm{~T}} \times 100 \%
$$

where LULCC is the rate of change of a certain land-use/land-cover (LULC) type for a certain time period; the subscripts $a$ and $b$ denote the beginning and the end of a time period for LULC change investigation, respectively; and $\mathrm{T}$ is the time period. A positive value means that there is an increasing trend for a specific time period for an area of a certain LULC type; otherwise, a deceasing trend is occurring for the area assessed. 

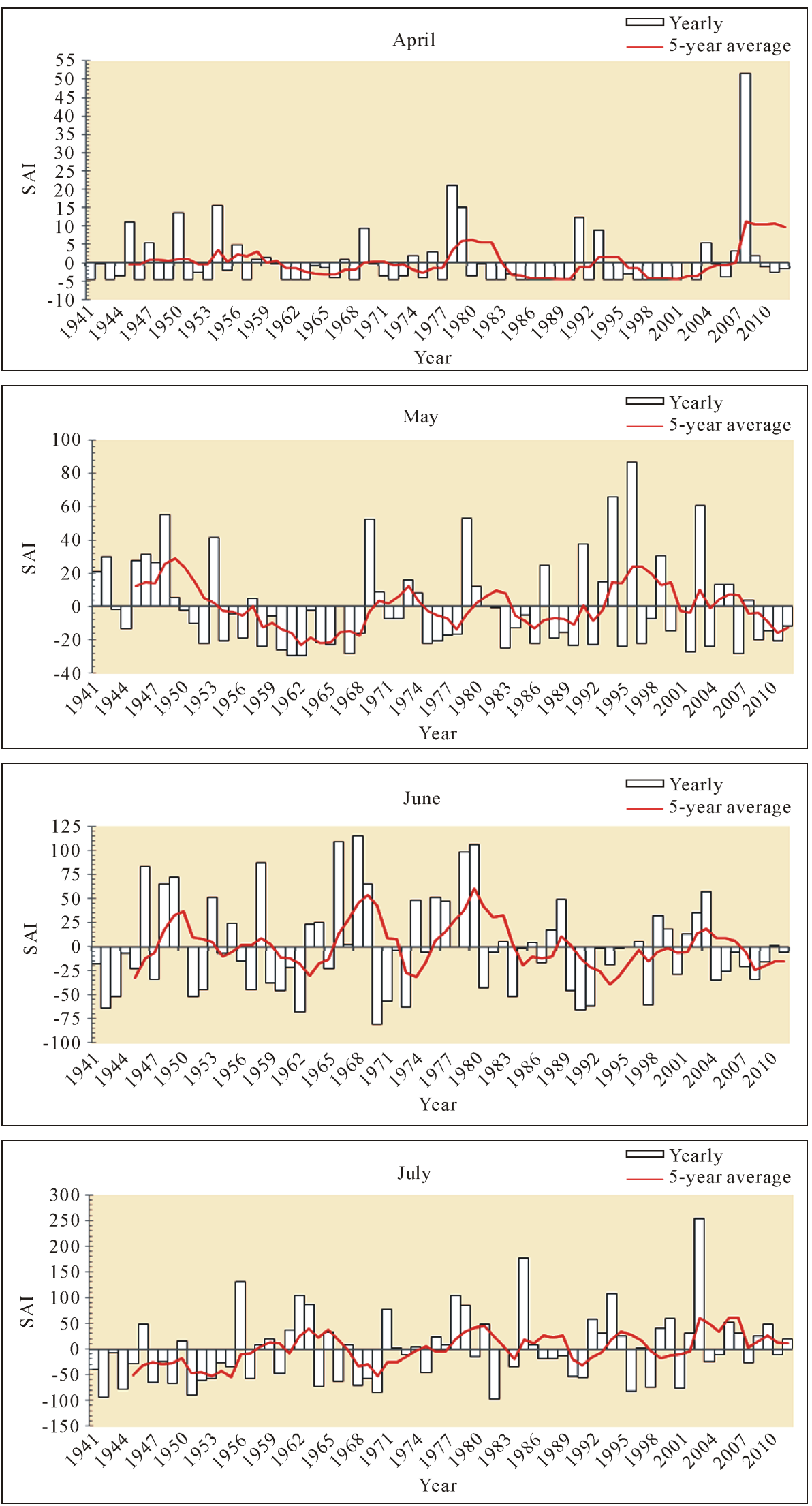

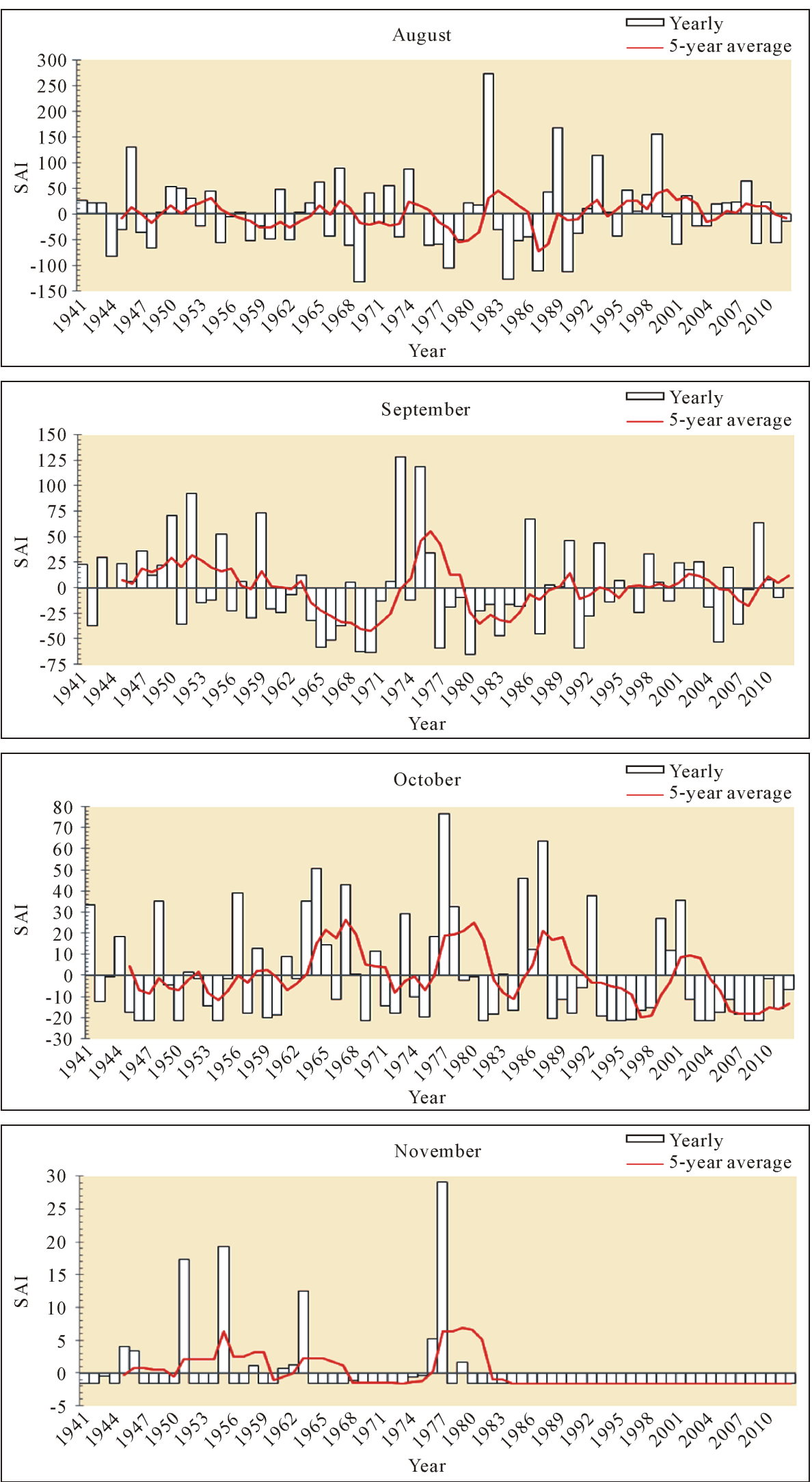

Figure 4. Monthly rainfalls in El Rawashda forest in 1941-2012. 
Table 1. Properties of the data used in the study.

\begin{tabular}{ccccc}
\hline [WRS: P/R] & Acquisition date & (Satellite) sensor & Sectral bands & Ground resolution (m) \\
\hline $171 / 050$ & 4 Nov. 1984 & Landsat 4 - 5 TM & $3-5$ & 30 \\
$171 / 050$ & 2 Dec. 1994 & Landsat 4 - 5 TM & $3-5$ & 30 \\
$171 / 050$ & 6 Dec. 2013 & Landsat 8 OLI/TIRS & $4-6$ & 30 \\
\hline
\end{tabular}

WRS $=$ World reference system; $\mathrm{P}=$ Path and $\mathrm{R}=$ Row; TM = Thematic Mapper; OLI = Operational Land Imager and TIRS and Thermal Infrared Sensor.

Supervised classification based on maximum likelihood algorithm was used in this study. ERDAS IMAGINE 9.2 image and ArcGIS 9.3 software were used for overall image processing. Using the nearest neighbor method, images were resample into a pixel size of $30 \times 30 \mathrm{~m}$. Amulti date PCC based change detection algorithm was used to determine the LULC changes in four periodic intervals: 1984 to 1994, 1994 to 2013 and 1984 to 2013. PCC is a quantitative method that requires an independent classification of individual images from different dates for the same geographic location, followed by a comparison of the corresponding pixels (thematic labels) in order to identify and quantify areas of changes [17]-[20]. It is the most commonly used method for LULC change detection mapping [21] [22]. Atmospheric correction was not applied in this study, because the adopted post classification comparison (PCC) approach compensated the variation in atmospheric conditions and vegetation phenology for different dates [23]-[25]. For LULC classification, a classification scheme, with four level 1 classes (Table 2), was adopted in this study [26]. The basic concepts and structure of this system are still valid today [27].

\section{Results and Discussions}

\subsection{The Experiment Layout and Field Work}

\subsubsection{Productivity}

We have analyzed dry productivity of forage (tons/feddan) in El Rawashda forest under different sowing treatments during two seasons (Table 5). There are significant differences regarding the productivity have been observed among the treatments. The highest productivity was under disc plowing followed by water harvesting and direct broadcasting during the two seasons. These variations in productivity might be attributed to conditions under each treatment. Under disc plowing the seeds were likely more protected and were enjoying better soil moisture compared to the seeds in other treatments. Moreover, from the results of plant cover and plant density (Table 2 and Table 3), higher plant cover and density were reported for disc plowing and water harvesting treatments. Therefore, it is expected to result in higher productivity as both growth parameters represent resultant to productivity. It is worth mentioning that productivity in late season was always greater than early season regardless of treatments used as late season productivity benefited from the rainfall since it was taken at the end of autumn.

\subsubsection{Vegetation Cover}

Table 3 showed vegetation cover in El Rawashda forest under different sowing treatments during the two seasons. Similar to the trend of productivity, the vegetation cover under disc plowing was the best compared to the other treatments including the control in two seasons.

\subsubsection{Plant Density}

Plant density in the present study under different sowing treatments during the two seasons showed in Table 4. The density was variable among the different treatments with the highest under disc plowing relative to others in the two seasons. This variation could be justified by variations in the planting conditions. Under disc plowing the seeds were likely more protected and were enjoying better soil moisture compared to the seeds in other treatments. Disc plowing besides preparing a good seedbed for the seeded species, it acts as micro catchment for rain water an assist in water infiltration into the soil. This will create a suitable environment for the young growing seedlings, consequently increasing plant density [28]. 
Table 2. Description of LULC classes identified in the study area.

\begin{tabular}{|c|c|}
\hline Classes & Descriptions \\
\hline Trees & All wooded areas with (75 - 300 trees/ha). This class includes trees shrubs \\
\hline MRA & Areas currently under crop or land being prepared for raising crops. \\
\hline Grasses & This class includes grasses used as grazing land. \\
\hline Bare land & $\begin{array}{l}\text { Non-vegetated areas such as bare rocks or areas with very little vegetation } \\
\text { cover of grasses also it used as grazing land. }\end{array}$ \\
\hline
\end{tabular}

Table 3. Vegetation cover (\%) under different sowing treatments.

\begin{tabular}{ccccc}
\hline \multirow{2}{*}{ Treatment } & \multicolumn{2}{c}{ Season one } & \multicolumn{2}{c}{ Season two } \\
\cline { 2 - 5 } & Early & Late & Early & Late \\
\hline Direct broadcasting & $0.7 \mathrm{~b}$ & $1.6 \mathrm{c}$ & $0.67 \mathrm{~b}$ & $1.64 \mathrm{~b}$ \\
Disc plowing & $0.75 \mathrm{a}$ & $1.9 \mathrm{a}$ & $0.75 \mathrm{a}$ & $1.82 \mathrm{a}$ \\
Water harvesting & $0.74 \mathrm{a}$ & $1.76 \mathrm{~b}$ & $0.71 \mathrm{a}$ & $1.69 \mathrm{~b}$ \\
Control & $0.62 \mathrm{c}$ & $1.4 \mathrm{~d}$ & $0.61 \mathrm{c}$ & $1.24 \mathrm{c}$ \\
LSD at 0.05 & 0.03 & 0.13 & 0.04 & 0.13 \\
CV\% & 18 & 14 & 15 & 13 \\
\hline
\end{tabular}

Figures followed by same letter(s) within each column are not significantly different at 0.05 level of probability using the LSD Test.

Table 4. Plant density $\left(\right.$ plant $\left./ \mathrm{m}^{2}\right)$ under different sowing treatments.

\begin{tabular}{ccccc}
\hline \multirow{2}{*}{ Treatment } & \multicolumn{2}{c}{ Season one } & \multicolumn{2}{c}{ Season two } \\
\cline { 2 - 5 } & Early & Late & Early & Late \\
\hline Direct broadcasting & 18.5 & 18.6 & 18.6 & 18.7 \\
Disc plowing & 20.4 & 21.1 & 20.6 & 20.1 \\
Water harvesting & 19.7 & 19.9 & 19.6 & 18.9 \\
Control & 17.1 & 17.4 & 17.2 & 17.4 \\
LSD at 0.05 & NS & NS & NS & NS \\
CV\% & 25 & 23 & 21 & 22 \\
\hline
\end{tabular}

\subsubsection{Carrying Capacity}

The carrying capacity (CC) is calculated on the average forage production data recorded for two seasons and the actual animal unit requirement. According to [29], not all herbage is forage, so we need to know the percentage of forage in the herbage. Usually, it is assumed that $50 \%$ of the herbage is usable forage. (Of course this value will differ from one range to another according to the vegetation type dominating the range). In El Rawashda forest the Percentage of Usable Forage (PUF) is 50\%. Table 5 shows the final productivity and CC, which were significantly higher under disc ploughing compared to the other treatments. These variations in CC might be attributed to conditions under each treatment. Under disc plowing the seeds were likely more protected and were enjoying better soil moisture compared with the seeds in the other treatments. 


\subsection{Satellite Images}

\subsubsection{Classification Accuracy Assessment and LULC Mapping}

In this study, the image processing approach was found to be effective in producing compatible LULC data over time, irrespective of the differences in spatial, spectral and radiometric resolution of the satellite data. According to the produced LULC map shown in Figure 5, was found that trees, MRA, Grasses and Bare land were the dominate types of LULC classes for the years 1984, 1994 and 2013. According to Table 6, percentages of LULC classes showed that in the year 1984, trees, MRA, Grasses and Bare land had occupied 94.2, 1.0, 2.3 and 2.5 percent of the study area, respectively. In the year 1994, trees, MRA, Grasses and Bare land had occupied 87.2, 1.6, 4.2 and 7, percent of the study area, respectively. In 2013 Trees, MRA, Grasses and Bare land had occupied 60.9, 9.6, 10.9 and 18.6 per cent of the study area, respectively. However, large decrease in Trees 94.2 to 87.2, 60.9 per cent was observed in the year 1984, 1994 and 2013 of the study area, respectively. Consequently large increased in MRA 1.0, 1.6 and 9.6 per cent was observed in the year 1984, 1994 and 2013 of the study area, respectively. Agriculture is the main economic activity, followed by livestock raising in the traditional seasonal transhumant pattern, village livestock raising and, as a recent element, livestock raising by large-scale mechanized merchant-farmers investing surplus wealth in cattle [30]. A significant increase of the MRA indicates of deforestation, mainly due to illegal over cutting of trees, which has been a continuing trend in the study area. The natural resources in developing countries like Sudan are continuously decreasing. Most of the population in Sudan is dependent on rain-fed agriculture and removal of forests for mechanized rain-fed has increased at high rate during the last few years [31]. A large increase of Grasses 2.3, 4.2 and 10.9 per cent was observed in the year 1984, 1994 and 2013, respectively in the study area. A large increase in the Barren land 2.5, 7 and 18.6 per cent was observed in the year 1984, 1994 and 2013, respectively. A high significant increase of the Barren land indicated deforestation, mainly due to illegal over cutting of trees. Figure 6 and Table 6 show large decreasing in Trees class 114465.2, 105913.5 and 74031.6 feddan in the year 1984, 1994 and 2013, respectively.

\subsubsection{LULC Change Analyses}

There exist a wide variety of methods to study LULC change [32] [33]. As all the images are classified separately based only on the information contained in each image, the post-classification comparison method by

Table 5. Forage productivity in El Rawashda forest in the first season.

\begin{tabular}{cccc}
\hline Treatment & $\begin{array}{c}\text { Yield productivity } \\
\text { (ton/feddan) }\end{array}$ & $\begin{array}{c}\text { Usable forage } \\
\text { (ton/feddan) }\end{array}$ & $\begin{array}{c}\text { Carrying capacity } \\
\text { (feddan/A.U./year) }\end{array}$ \\
\hline Direct broadcasting & 1.6 & 0.8 & 5.48 \\
Disc plowing & 1.9 & 0.95 & 4.61 \\
Water harvesting & 1.76 & 0.88 & 4.98 \\
Control & 1.4 & 0.7 & 6.26 \\
\hline
\end{tabular}

Table 6. Areas and percentages of LULC classes for the period 1984-2013.

\begin{tabular}{|c|c|c|c|c|c|c|}
\hline \multirow{2}{*}{ LULC } & \multicolumn{2}{|c|}{1984} & \multicolumn{2}{|c|}{1994} & \multicolumn{2}{|c|}{2013} \\
\hline & Area (feddan) & Area (\%) & Area (feddan) & Area (\%) & Area (feddan) & Area (\%) \\
\hline Trees & 114465.2 & 94.2 & 105913.5 & 87.2 & 74031.6 & 60.9 \\
\hline MRA & 1253.8 & 1 & 1978.9 & 1.6 & 11643.0 & 9.6 \\
\hline Grasses & 2769.9 & 2.3 & 5085.0 & 4.2 & 13225.3 & 10.9 \\
\hline Bare land & 2983.7 & 2.5 & 8495.1 & 7 & 22572.6 & 18.6 \\
\hline Total & 121472.6 & 100 & 121472.6 & 100 & 121472.6 & 100 \\
\hline
\end{tabular}



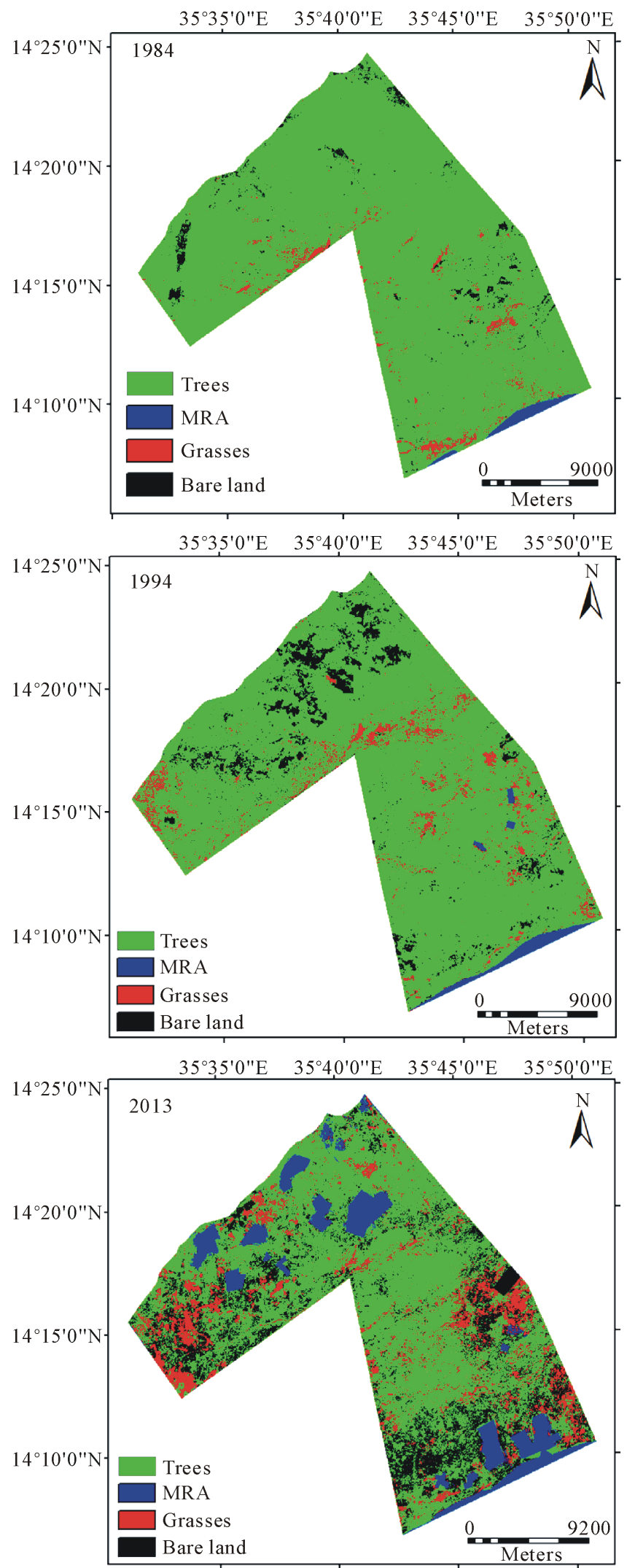

Figure 5. LULC map in 1984, 1994 and 2013. 


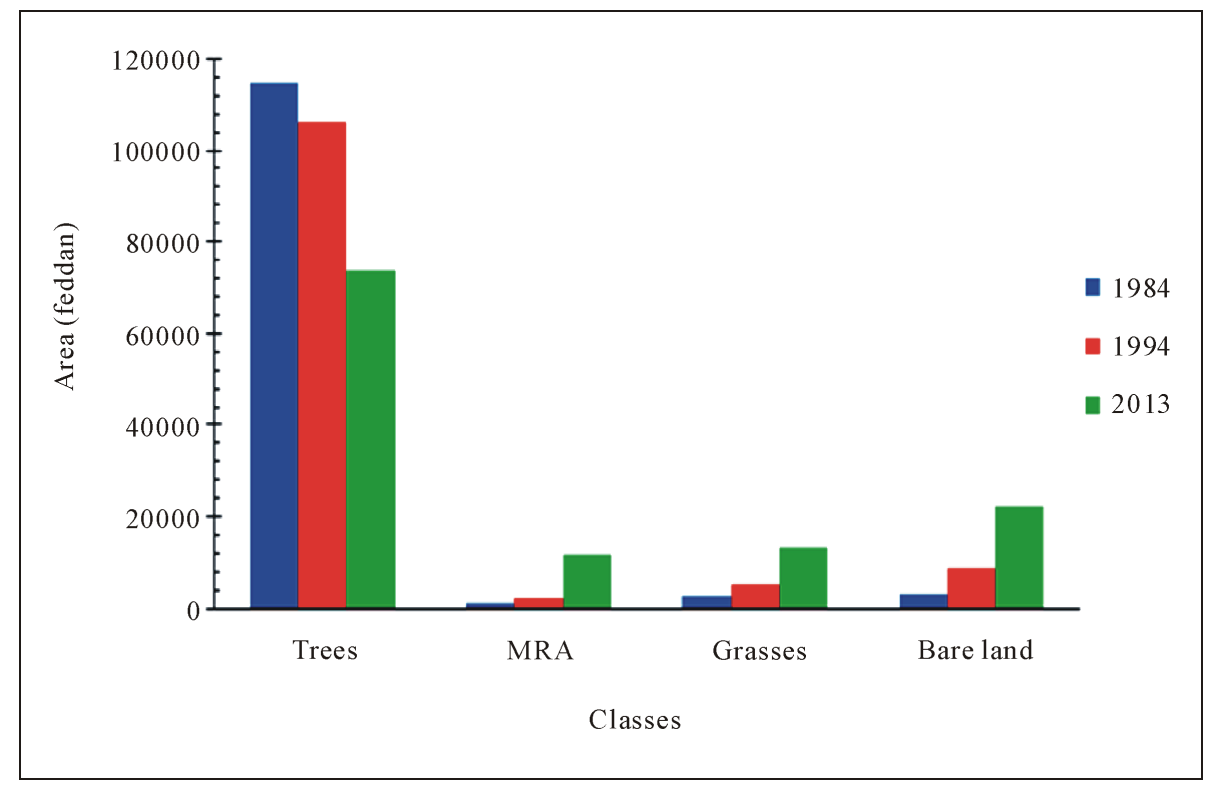

Figure 6. Areas distribution comparison of different LULC classes in 1984, 1994 and 2013.

Foody [34], for change detection was used for this study. With the help of this method Thematic Maps of two dates are compared on pixel-by-pixel basis to extract the change that may have occurred between time periods. There exist four LULC classes in classified maps and every class is represented by one unique code (i.e. pixel value) range from 1 to 4 . To detect the change from 1984 to 1994, the LULC 1984 map is multiplied with 10. Then both image 1984 and 1994 added together. All other pixel values show the change that occurred in the image. Same procedure was adopted to detect the change from 1994 to 2013 and 1984 to 2013.In the study area, LULC classes have changed significantly. The changes are normally quantified per pixel counts, areas or percentages. Different classes were represented as different colures in each image, making it easy to identify not only where changes have taken place but also the class into which the pixels have changed. The change detection statistics for three decades of the study area are presented in Table 6. The statistics in Table 7, Table 8 and Table 9, show that the MRA areas has increased significantly, covering approximately 77, 85 and 87 per cent of the trees for the year 1984 to 1994, 1994 to 2013 and 1984 to 2013, respectively. Large grasses areas increased significantly as well, covering approximately 84, 94 and 61 per cent of the Trees for the year 1984 to 1994, 1994 to 2013 and 1984 to 2013, respectively. Large Barren land areas also increased high significantly, covering approximately 91, 95 and 94 per cent of the Trees for the year 1984 to 1994, 1994 to 2013 and 1984 to 2013, respectively. This result is in conformity with [35], showed that at present natural forest in Sudan is estimated to have declined to approximately 0.8 billion $\mathrm{m}^{3}$ standing crop, while it was 2.4 billion $\mathrm{m} 3$ in mid seventies. Since the time when reservation of natural forests started in 1932, the policy was to concentrate on the management of forests reserves under government control, to organize felling program, protection, conservation, development and management. [36] mentioned Over-grazing is among the causes of desertification in the Sudan. Land degradation is a global problem associated with desertification, loss of biological diversity and deforestation in dry lands, which covers some 47 per cent of the Earth's surface. Figure 7, in which the light blue (MRA) areas, light red (Grasses) areas, light black (Bare land) have increased over the years. According to Table 10, conversion of classes of Trees to MRA, Tress to Grasses and Trees to Bare land is 9913.7, 12467.6 and 21355.1 feddans in 1984 to 2013, respectively. Table 11 and Figure 8 presented the annual LULC changes for the duration of this study period. During study period 1984-1994, 1994 to 2013 and 1984 to 2013 the percentage of MRA increased 5.78, 25.70 and 28.57, respectively. Also the percentage of grasses increased 8.36, 8.43 and 13.02. [37], concluded that the main cause of desertification is human over-exploitation of lands through over-cultivation, over cutting and over grazing of wood. All these are conflicting and sometimes antagonistic land use pattern. The percentage of Bare land increased 18.47, 8.72 and 22.64, respectively. On the other hand, the percentage of Trees decreased $-0.75,-1.58$ and -1.22 , respectively (Table 11 and Figure 8). 
$35^{\circ} 30^{\prime} 0^{\prime \prime} \mathrm{E} \quad 35^{\circ} 35^{\prime} 0^{\prime \prime} \mathrm{E} \quad 35^{\circ} 40^{\prime} 0^{\prime \prime} \mathrm{E} \quad 35^{\circ} 45^{\prime} 0^{\prime \prime} \mathrm{E} \quad 35^{\circ} 50^{\prime} 0^{\prime \prime} \mathrm{E}$
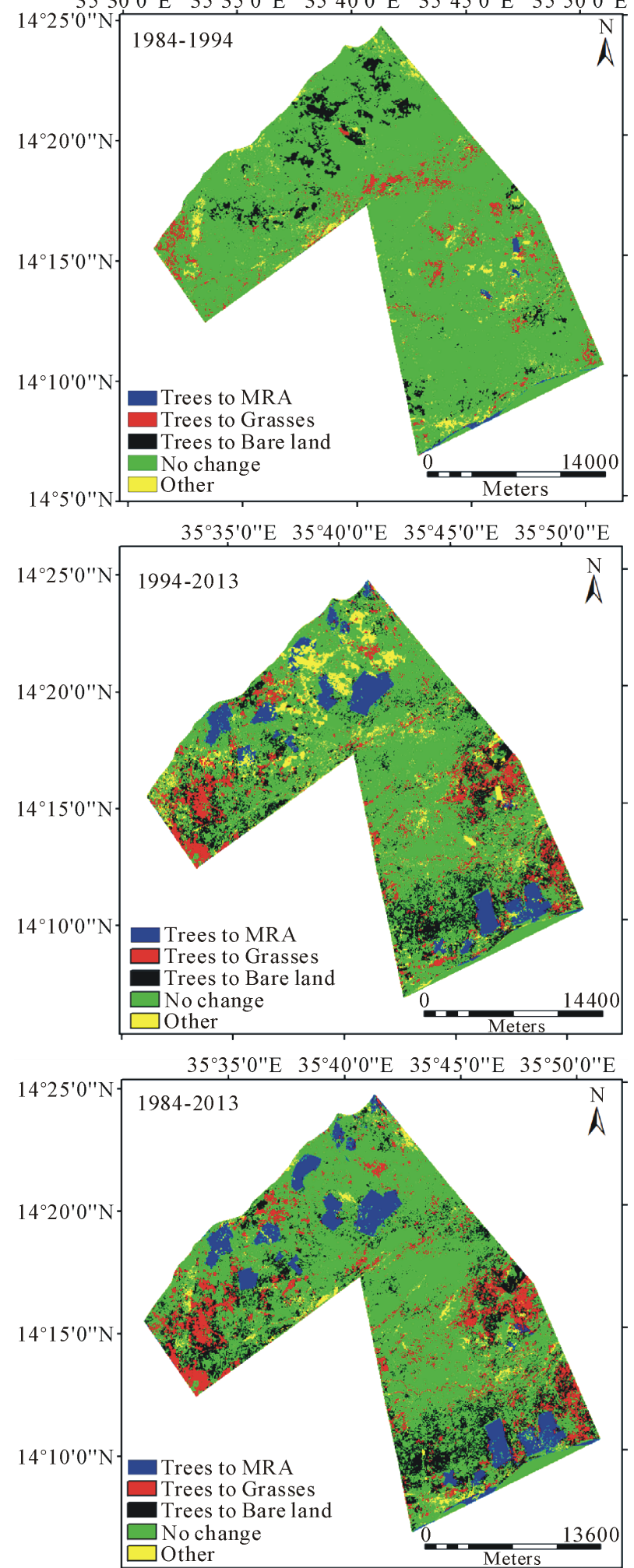

Figure 7. Post classification change analysis 1984-1994, 1994-2013 and 1984-2013 image classification. No change is: Trees to Trees, MRA to MRA, Grasses to Grasses and Bare land to Bare land; Other is: MRA to Trees, Grasses to Trees, Bare land to Trees, MRA to Grasses, MRA to Bare land, Grasses to MRA, Grasses to Bare land, Bare land to MRA and Bare land to Grasses. 
Table 7. Change detection (per cent) of LULC for the period 1984-1994.

\begin{tabular}{ccccc}
\hline Change from & Trees & MRA & Grasses & Bare land \\
\hline Trees & $\mathbf{8 8}$ & 77 & 84 & 91 \\
MRA & 0 & $\mathbf{1 4}$ & 1 & 0 \\
Grasses & 4 & 1 & $\mathbf{1 0}$ & 3 \\
Bare land & 7 & 8 & 6 & $\mathbf{6}$ \\
\hline
\end{tabular}

Data in bold represent unchanged fractions of each class.

Table 8. Change detection (per cent) of LULC for the period 1994-2013.

\begin{tabular}{ccccc}
\hline Change from & Trees & MRA & Grasses & Bare land \\
\hline Trees & $\mathbf{9 6}$ & 85 & 94 & 95 \\
MRA & 0 & $\mathbf{1 1}$ & 0 & 0 \\
Grasses & 2 & 2 & $\mathbf{3}$ & 2 \\
Bare land & 2 & 2 & 3 & $\mathbf{3}$ \\
\hline
\end{tabular}

Data in bold represent unchanged fractions of each class.

Table 9. Change detection (per cent) of LULC for the period 1984-2013.

\begin{tabular}{ccccc}
\hline Change from & Trees & MRA & Grasses & Bare land \\
\hline Trees & $\mathbf{9 4}$ & 87 & 61 & 94 \\
MRA & 1 & $\mathbf{2}$ & 10 & 1 \\
Grasses & 2 & 4 & $\mathbf{1 1}$ & 2 \\
Bare land & 2 & 7 & 19 & $\mathbf{2}$ \\
\hline
\end{tabular}

Data in bold represent unchanged fractions of each class.

Table 10. Conversion of classes from one class to another.

\begin{tabular}{cccc}
\hline LULC classes & $\begin{array}{c}1984 \text { to } 1994 \\
\text { (feddan) }\end{array}$ & $\begin{array}{c}1994 \text { to } 2013 \\
\text { (feddan) }\end{array}$ & $\begin{array}{c}1984 \text { to } 2013 \\
\text { (feddan) }\end{array}$ \\
\hline Trees to MRA & 656.8 & 8939.8 & 9913.7 \\
Trees to Grasses & 4687.1 & 11088.9 & 12467.6 \\
Trees to Bare land & 7997.1 & 20482.1 & 21355.1 \\
MRA to Trees & 3 & 235.5 & 8.8 \\
MRA to Grasses & 0.2 & 66.2 & 4.1 \\
MRA to Bare land & 1.1 & 27.2 & 0.4 \\
Grasses to Trees & 2355 & 2980.7 & 1681.9 \\
Grasses to MRA & 28.7 & 146.8 & 229.1 \\
Grasses to Bare land & 60.4 & 650.8 & 453.0 \\
Bare land to Trees & 2431.3 & 5412.6 & 1612.1 \\
Bare land to MRA & 43.9 & 906.4 & 259.7 \\
Bare land to Grasses & 72.0 & 763.5 & 347.8 \\
\hline
\end{tabular}


Table 11. Annual LULC change rates (\%) for the three study sites.

\begin{tabular}{cccc}
\hline LULC classes & $1984-1994$ & $1994-2013$ & $1984-2013$ \\
\hline Trees & -0.75 & -1.58 & -1.22 \\
MRA & 5.78 & 25.70 & 28.57 \\
Grasses & 8.36 & 8.43 & 13.02 \\
Bare land & 18.47 & 8.72 & 22.64 \\
\hline
\end{tabular}

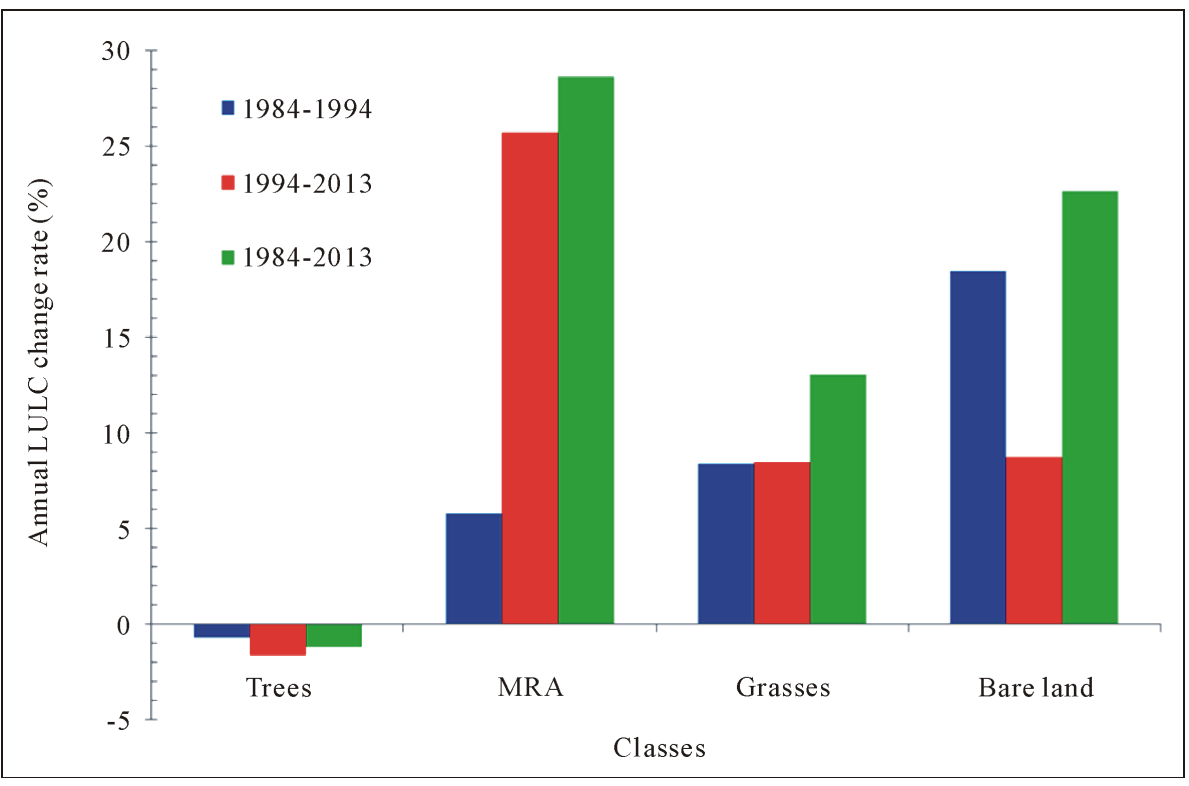

Figure 8. Annual LULC change rates for the three study sites.

\section{Conclusion}

The LULC changes for the different years are represented in Figure 7 and Figure 9(a), Figure 9(b), Figure 9(c), and Figure 9(d); it can be observed that Trees areas decreased in all the years. The Trees class was highly dynamic, leaving behind only 74031.6 feddans of the original woodland areas in the year 2013 (Table 6). According to Table 10 and Figure 9(a), Figure 9(b) and Figure 9(c), conversion of classes of Trees to MRA, Tress to Grasses and Trees to Barren land is 9913.7, 12467.6 and 21355.1 feddans in 1984 to 2013, respectively. The current study shows a successful application of multi-temporal Landsat data and maximum likelihood algorithm in mapping LULC classes of the years 1984, 1994 and 2013 in Sahelian environments. The maximum likelihood classification along with masking technique has ability to produce a good classification results. The results are presented in the form of maps, statistical tables and charts. These include the spatial distribution and change of LULC classes in each time period of the study. A comparison between two images was made both visually and digitally to identify the changes and transformation that has occurred from one class to the other over the years. Analyzing and mapping the trend of LULC dynamics within the study area provide a basis for strategic planning, management and conservation decision making, because changes in the LULC will have strong local, social and environmental implications, such as alterations in social stability, conflicts on natural resources, impacts on rates and types of land deforestation and thus can reduce biodiversity. This study shows that remote sensing imagery from different sensor can be used to monitor the LULC changes over long periods in Sahelian environments like Sudan. These low cost change analysis procedures made it possible to quantify and map the change patterns in both trees land and other LULC classes. The forest in Sudan is decreasing at a alarming rate. In Gadarif state, desolation of forest for the expansion of agricultural area is one of the major sources for the degradation of renewable resources [38]. The period 1984 to 2013 shows the intensive clearance of trees due to illegal activities. Also the high increase in MRA, this is due to more areas had became Bare land, 


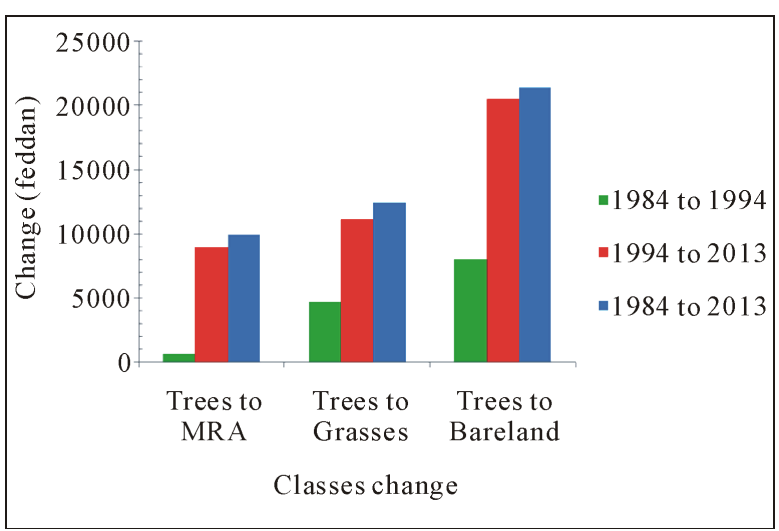

(a)

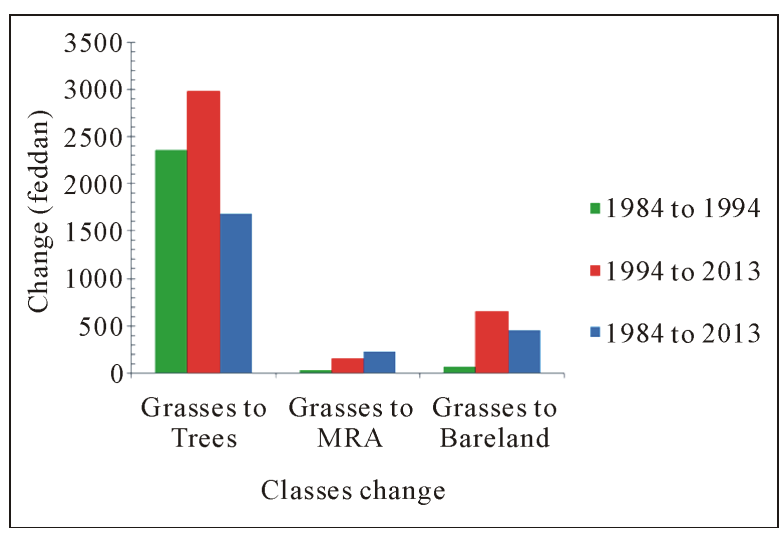

(c)

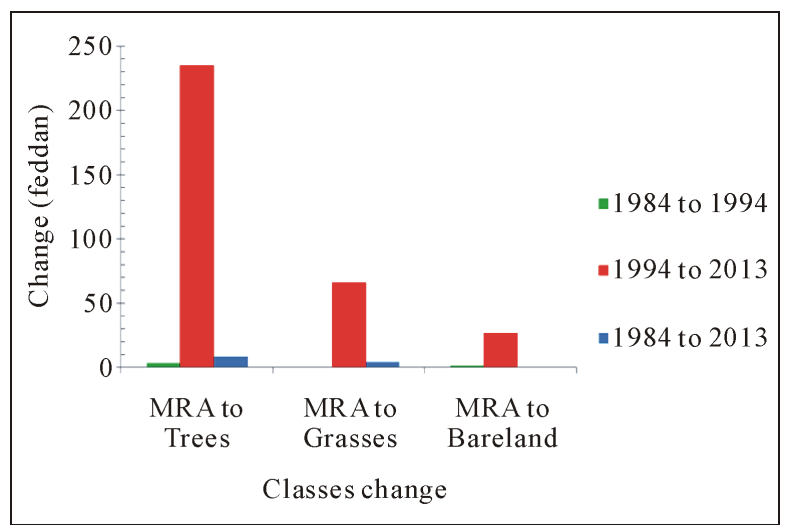

(b)

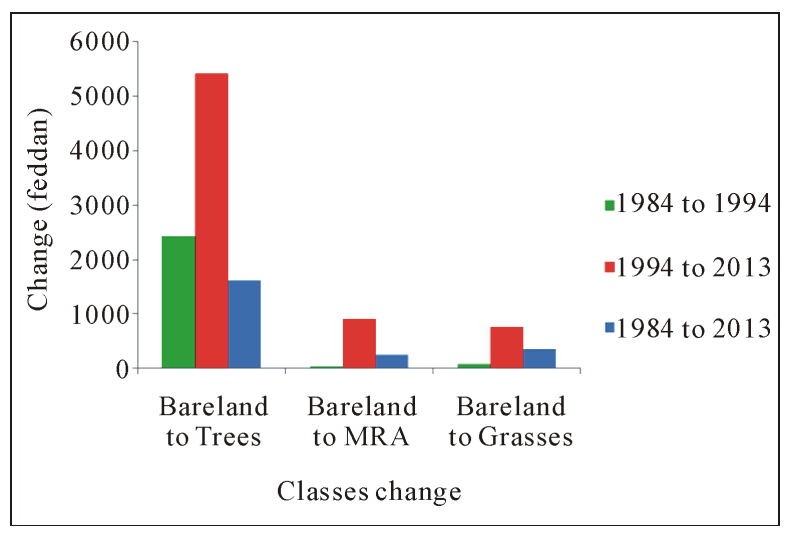

(d)

Figure 9. (a), (b), (c), and (d) LULC changes in different classes.

these areas were cultivated by farmer according to a contract between forests national corporation (FNC) administration and farmer, farmer must be pay $15 \%$ of the crop productivity for FNC. The situation about LULC in all the period of study Trees class was decreased and the anther classes MRA, Grasses and Bare land were increased. Nomads are staying in the forest for varying periods of time with their livestock using the forest as pasture. Deforestation resulted from intensive activities of nomads which included grazing and lopping trees. Different factors are responsible for the deterioration of rangeland and tree cover in El Rawashda forest, the main factors are: over-cutting of wood (illicit felling), over grazing due to increase in animal population and this resulted in depletion of forage and replacement by unpalatable grasses. Deterioration is also due to over cultivation by traditional or mechanized farming, population increase and climate change. The main reported recommendation for rangeland and trees cover rehabilitation include: disc plowing with seed broadcasting, water harvesting technique with seed broadcasting and direct seed broadcasting. There is a significant difference among treatments in forage productivity and vegetation cover. Disc plowing is significantly higher followed by water harvesting then broadcasting seed and lastly control. Seeds used in the experiment include seeds of Convolvulus spp (Tabar), Ipomea cardiosepla (Hantoot), Blepharis edulis (Siha), Tribulus terristris (Derasa) and Rhyncosia memnonia (Adana) in addition to seeds of Acacia seyal (Talih).

\section{Recommendations}

Here are recommendations for further research on the use of remote sensing in monitoring LULC changes in Sudan. Particularly these studies not only improve our understanding about LULC changes and its implications in management and conservation efforts, but also will provide perspectives for the planner in sustainable development of LULC at the whole country. However, we do think that there is still need for further work on the use of remote sensing for LULC changes covering whole land area of Sudan. For instance how we could couple these multi-temporal data with ground assessment. Forest and rangeland authorities should increase the use of 
disc plowing more than water harvesting techniques and direct broadcasting of seeds for the enrichment of the rangeland and tree cover. Enactment of laws and grazing licenses to regulated the movement of the nomads, Introduction of deferred grazing system which will give a chance for the plants to regenerate and spread on the area in comparison with the grazing system.

\section{Acknowledgements}

This paper is partially supported by Specialized Research Fund for the Doctoral Program of Higher Education (20136203110002) and National Natural Science Foundation of China (No. 40961038). The first author would like to thank China Scholarship Council CSC for awarding scholarship to work at Northwest Normal University. I also thank the referee for his or her valuable comments.

\section{References}

[1] FAO (1997) State of the World's Forest. Situation and Prospects for Forest Conservation and Development, Italy.

[2] Craig, M.G. (1991) The Agriculture of the Sudan. Center for Agriculture Strategy, University of Reading. Oxford UP, London.

[3] SKAP (Southern Kassala Agricultural Project) (1992) Land Use Survey Report (Main Report), Vol. 1, Khartoum, Sudan.

[4] Yıldırım, H., Alparslan, E. and Ozel, M.E. (1995) Temporal Change Detection by Principal Component Transformation on Satellite Imagery. Paper Presented at IEEE International Geosciences and Remote Sensing Symposium, Florence.

[5] Turner, W., Spector, S., Gardiner, N., Fladeland, M., Sterling, E. and Steininer, M. (2003) Remote Sensing for Biodiversity Science and Conservation. Trends in Ecology and Evolution, 18, 306-314. http://dx.doi.org/10.1016/S0169-5347(03)00070-3

[6] Woodcock, C.E., Macomber, S.A., Pax-Lenney, M. and Cohen, W.B. (2001) Monitoring Large Areas for Forest Change Using Landsat: Generalization across Space, Time and Landsat Sensors. Remote Sensing of Environment, 78, 194-203.

http://www.sciencedirect.com/science?_ob=ArticleListURL\&_method=list\&_ArticleListID=-767547156\&_sort=r\&_st $=13 \&$ view=c\&md5=e8a2a95dccfc685311a043ce48bdfe10\&searchtype $=\mathrm{a}$

[7] Watson, N. and Wilcock, D. (2001) Reclassification as an Aid to the Improvement of the Thematic and Spatial Accuracy in Land Covers Maps Derived from Satellite Imagery. Remote Sensing of Environment, 75, 267-278. http://dx.doi.org/10.1016/S0034-4257(00)00172-3

[8] Scanlon, T.M., Albertson, J.D., Caylor, K.K. and Williams, C.A. (2002) Determining Land Surface Fractional Cover from NDVI and Rainfall Time Series for a Savanna Ecosystem. Remote Sensing of Environment, 82, 376-388. http://dx.doi.org/10.1016/S0034-4257(02)00054-8

[9] Fuller, R.M., Smith, G.M. and Devereux, B.J. (2003) The Characterization and Measurement of Land Cover through Remote Sensing: Problems in Operational Applications. International Journal of Applied Earth Observation and Geoinformation, 4, 243-253. http://dx.doi.org/10.1016/S0303-2434(03)00004-7

[10] Hamdoun, M.A., Ageeb, A.O. and Dawelbeit, I.M. (1991) Review on Applied Research Simsim Dry Land Farming. CRC Press, Boca Raton.

[11] Hineit, B.M. (2007) Effect of Type, Time of Tapping and Tree Size of Acacia Seyal on the Product of Gum Talha in El Rawashda Forest, Gadaref State, Sudan. University of Khartoum, Faculty of Forestry, Khartoum.

[12] Elhag, M.M. (2006) Causes and Impact of Desertification in the Butana Area of Sudan. Ph.D. Thesis, University of the Free State, Bloemfontein.

[13] Gomez, K.A. and Gomez, A.A. (1984) Statistical Procedures. 2nd Edition, John Wiley and Sons, New York.

[14] Parker, K. (1951) A Method for Measuring Trend in Range Condition on Natural Forest Ranges. US Forestry Service, Washington (Mimeo).

[15] Peterson, D.L., Egbert, S.L., Price, K.P. and Martinko, E.A. (2004) Identifying Historical and Recent Land-Cover Changes in Kansas Using Post-Classification Change Detection Techniques. Transactions of the Kansas Academy of Science, 107, 105-118. http://dx.doi.org/10.1660/0022-8443(2004)107[0105:IHARLC]2.0.CO;2

[16] Petit, C.C. and Lambin, E.F. (2001) Integration of Multi-Source Remote Sensing Data for Land Cover Change Detection. International Journal of Geographical Information Science, 15, 785-803.

http://dx.doi.org/10.1080/13658810110074483 
[17] Rutchey, K. and Velcheck, L. (1994) Development of an Everglades Vegetation Map Using a SPOT Image and the Global Positioning System. Photogrammetric Engineering and Remote Sensing, 60, 767-775.

[18] Chen, X.W. (2002) Using Remote Sensing and GIS to Analyze Land Cover Change and Its Impacts on Regional Sustainable Development. International Journal of Remote Sensing, 23, 107-124. http://dx.doi.org/10.1080/01431160010007051

[19] Jensen, J.R. (2005) Introductory Digital Image Processing. 3rd Edition, Prentice-Hall, Upper Saddle River.

[20] AlFugara, A.M., Pradhan, B. and Mohamed, T.A. (2009) Improvement of Land Use Classification Using Object Oriented and Fuzzy Logic Approach. Applied Geomatics, 1, 111-120. http://dx.doi.org/10.1007/s12518-009-0011-3

[21] Petit, C.C. and Lambin, E.F. (2002) Impact of Data Integration Technique on Historical Land Use/Land Cover Change: Comparing Historical Maps with Remote Sensing Data in the Belgian Ardennes. Landscape Ecology, 17, 117-132. http://dx.doi.org/10.1023/A:1016599627798

[22] Kamusoko, C. and Aniya, M. (2009) Hybrid Classification of Landsat Data and GIS for Land Use/Cover Change Analysis of the Bindura District, Zimbabwe. International Journal of Remote Sensing, 30, 97-115. http://dx.doi.org/10.1080/01431160802244268

[23] Coppin, P., Jonckheere, I., Nackaerts, K., Muys, B. and Lambin, E. (2004) Digital Change Detection Methods in Ecosystem Monitoring: A Review. International Journal of Remote Sensing, 25, 1565-1596. http://dx.doi.org/10.1080/0143116031000101675

[24] Yuan, F., Bauer, M.E., Heinert, N.J. and Holden, G. (2005) Multi-Level Land Cover Mapping of the Twin Cities (Minnesota) Metropolitan Area with Multi Seasonal Landsat TM/ETM+ Data. Geocarto International, 20, 5-13. http://dx.doi.org/10.1080/10106040508542340

[25] Youssef, M.A., Pradhan, B. and Tarabees, E. (2010) Integrated Evaluation of Urban Development Suitability Based on Remote Sensing and GIS Techniques: Contribution from the Analytic Hierarchy Process. Arabian Journal of Geosciences, 4, 463-473. http://dx.doi.org/10.1007/s12517-009-0118-1

[26] Anderson, R., Hardy, E.E., Roach, J.T. and Witmer, R.E. (1976) A Land Use and Land Cover Classification System for Use with Remote Sensor Data. USGS Professional Paper 964, Sioux Falls.

[27] Lillesand, T.M., Kiefer, R.W. and Chipman, J.W. (2008) Remote Sensing and Image Interpretation. John Wiley \& Sons, Inc., New York, 213.

[28] Abusuwar, A., Dixon, R.M. and Schonhorst, M.H. (1993) Imprintation Inter-Seeding, Soil Moisture and Seedling Emergence. University of Khartoum Journal of Agriculture Sciences, 1, 59-80.

[29] Abusuwar, A. (2007) Range Management UNESCO CHAIR ON DESRTIFICATION (Text Book). Khartoum University Press, Khartoum.

[30] Sulieman, H.M. (2008) Mapping and Modelling of Vegetation Changes in the Southern Gadarif Region, Sudan, Using Remote Sensing e Land-Use Impacts on Biophysical Processes. TUD Press, Dresden.

[31] Biswas, A.K., Masakhalia, Y.F.O., Odero-Ogwel, L.A. and Pallangyo, E.P. (1987) Land Use and Farming Systems in the Horn of Africa. Land Use Policy, 4, 419-443. http://dx.doi.org/10.1016/0264-8377(87)90064-0

[32] Singh, A. (1989) Digital Change Detection Techniques Using Remotely-Sensed Data. International Journal of Remote Sensing, 10, 989-1003. http://dx.doi.org/10.1080/01431168908903939

[33] Muchoney, D.M. and Haack, B.N. (1994) Change Detection for Monitoring Forest Defoliation. Photogrammetric Engineering and Remote Sensing, 60, 1243-1251.

[34] Foody, G.M. (2003) Remote Sensing of Tropical Forest Environments: Towards the Monitoring of Environmental Resources for Sustainable Development. International Journal of Remote Sensing, 24, 4035-4046. http://dx.doi.org/10.1080/0143116031000103853

[35] Mohamed, G.E. (2008) Socioeconomic Aspects of Natural Vegetation Cover Affecting Rural Communities Sustainable Livelihood. Case Study, North White Nile State.

[36] HCENR (2009) The Higher Council for Environment and Natural Resources, Government of the Republic of Sudan, Ministry of Environment and Physical Development. Sudan's Fourth National Report to the Convention on Biological Diversity, Khartoum.

[37] Tolba, M.K. (1984) Harvest of Dust. Desertification Control Bulletin No 10 UNER, Nairobi, 2.4.

[38] Sulieman, H.M. and Buchroithner, M.F. (2009) Degradation and Abandonment of Mechanized Rain-Fed Agricultural Land in the Southern Gadarif Region, Sudan: The Local Farmers’ Perception. Land Degradation and Development, 20, 199-209. http://dx.doi.org/10.1002/ldr.894 